\title{
Digital Modernization of the Russian Mining Sector in Accordance with the National Technology Initiative and Mining 4.0
}

\author{
Elena Dotsenko ${ }^{1, *}$, Natalia Ezdina ${ }^{1}$, Natalia Breider $^{2,3}$, and Samer Khouri $^{4}$ \\ ${ }^{1}$ Plekhanov Russian University of Economics, Department of Political Economy and History of \\ Economic Science, 11799736 Stremyanny lane, Moscow, Russia \\ ${ }^{2}$ Saint-Petersburg Scientific-Research Institute for Physical Culture, 191040 56E Ligovsky av., Saint \\ Petersburg, Russia \\ ${ }^{3}$ Russian State Hydrometeorological University, 79 Voronezhskaya st., Saint Petersburg, Russia \\ ${ }^{4}$ Technical University Košice, Faculty BERG, Letná 9, 04001 Košice, Slovakia
}

\begin{abstract}
Currently, a new impetus for the innovative development of the Russian economy is associated with the formation and implementation of measures within the framework of the National Technology Initiative, aimed at the expansion of national high-tech companies into world markets. At the same time, there is a large-scale consumer of Industry 4.0 technologies in the domestic market - the extractive sector of the Russian industry, in need of technological support for innovative modernization. Today, the mining industry around the world is in a process of technological transformation, as digital and automated technologies are transforming traditional technologies for the extraction of energy and non-energy minerals. In the era of volatile global demand for raw materials, stricter safety and environmental requirements and dwindling profits, the mining industry must increase its investment attractiveness by radically increasing productivity as a result of the introduction of intelligent mining systems. Thus, new technological requirements of the Russian mining industry can be satisfied within the key areas of the National Technology Initiative. For this, it is important to unite the efforts of representatives of business, the scientific and educational community, the state, and international partners in the interests of the technological modernization of the mining complex as a factor of national economy development.
\end{abstract}

\section{Introduction}

The National Technology Initiative as a new institution for enhancing innovative activity is a long-term strategy for the modernization of the Russian economy and society, aimed at creating new markets and ensuring conditions for the country's full-fledged presence in hightech markets by 2035 [1] The production and technological benchmark for the National

\footnotetext{
* Corresponding author: ktyf110372@,rambler.ru
} 
Technology Initiative is Industry 4.0 [2]. The European Union technology platforms created in the 2000s served as an example for the National Technology Initiative. [3]

The roadmaps for the innovative development of the Russian economy within the framework of the National Technology Initiative are divided into three categories:

- markets that require expensive infrastructure and imply significant government participation (AutoNet, MariNet, SafeNet, TechNet, EnergyNet);

- markets associated with certain risks and implying the development of public-and-private partnerships in the innovation field (AeroNet, HealthNet, NeuroNet, FoodNet);

- markets with moderate risks that do not require state funding for innovative projects (WearNet, EduNet, EcoNet, GameNet, HomeNet, SportNet).

At a first glance, it seems that the directions of development of the Russian National Technology Initiative are related to the manufacturing sector and intangible high-tech services, which is the "core" of Industry 4.0 technologies. However, Industry 4.0 opens up new horizons for mining industry development, creating new opportunities for productivity growth with improved labour safety. The upcoming stage of innovative development of geotechnology (Mining 4.0 - Industry 4.0 in mining) is associated with the placing the mining into the category of high-tech industries, thanks to the introduction of modern digital technologies [4]. Such technologies include unmanned robotic complexes of mining and quarry equipment, digital flow telemetry, the Internet of Things (machine-to-machine communications), digital 3D clones of engineering objects and artificial intelligence in processing large arrays of engineering, financial, economic and management information.

\section{Materials and Methods}

The platform development of stimulating innovation activity was launched in the countries of the European Union in 2001, with the beginning of the formation of European technology platforms. Its initiators recognized the need not only to increase investment in R\&D, but also to ensure the coordination of demand and supply of innovations at the pan-European, national and regional levels. One of the key means of such coordination was the European technology platforms, aimed at integrating the efforts of key industrial actors, representatives of industrial and financial business, national and regional authorities, the universities and academic community, non-governmental organizations and civil society [5-7].

The first European technology platform was named the Advisory Council for Aeronautics Research in Europe - ACARE. The first large-scale intellectual product created on its basis was the strategic plan for industry research. Due to the fact that market products created with the participation of European technology platforms are formed with the support of supranational structures of the European Union, their funding includes a significant proportion of pre-competitive research, laying the fundamental foundations for creating future innovations. That is, with the help of a wide range of platform interactions, the European Union created an integrated research program, which was interested not only in the scientific community, but also in industry.

To date, 38 European technology platforms have been created; on the basis of some of them, higher-level stratagems were launched (Joint Technology Initiatives). Technology platforms are focused on innovative modernization of the economy, increasing the competitiveness of certain industries and reducing the resource intensity of raw materials sectors, solving significant social problems (health, safety, ecology, education, culture), as well as stimulating the development of new markets for high-tech products and, accordingly, new companies in these areas.

The most important characteristic of all European technology platforms is that the very process of their creation is formed according to the "bottom-up" principle, which reflects their essence of voluntary forms of integration and self-organization of stakeholders, in the 
form of an extended advisory council. Basically, the largest industrial corporations and alliances act as initiators and coordinators of the activities of European technology platforms.

The Russian National Technology Initiative, developed since 2014, has incorporated the positive aspects of European technology platforms, as well as the experience of developing Russian technology platforms, which have been created since 2009 in the amount of 27. Taking into account the positive and negative aspects of the evolution of national and European technology platforms, as well as the Joint Technology Initiatives of the European Union [8] made it possible to highlight the key differences between them and the Russian National Technology Initiative:

1. Emphasis on personal connections between members of the academic community, innovative entrepreneurs and top management of industrial enterprises regarding the involvement of intellectual capital in production. The National Technology Initiative is being formed as a broad creative community, involving the formation of project teams from innovative entrepreneurs, representatives of leading universities and research centers, large business associations of Russia, development institutions, expert and professional communities, as well as interested government bodies.

2. Advance focus of joint efforts on the emerging global high-tech markets, the struggle for leadership in which will take place on the horizon of the next 20 years in the process of total digitalization of the world economy [9]. Undoubtedly, these areas give Russian innovative entrepreneurs the greatest chances for market leadership, especially if the extractive sector a key structural element of the Russian economy - is involved in the orbit of demand for innovation. Current trends in the global high-tech market attempt to catch up with world leaders, as well as to effectively use their business models in Russian conditions, futile. This is due to the high risks of entering competitive oligopoly markets and significant investment lags for such firms.

3. The greatest market success is achieved in those areas where the collaboration of equal partners is developing, capable of effectively coping with global technological challenges. In this regard, the National Technology Initiative includes a priority focus on the advanced training of talented researchers, engineers and entrepreneurs in segments of the most promising markets, including means of digitalization of mining.

4. The National Technology Initiative is associated with the creation of a significant scientific and technical groundwork for breakthrough areas of innovative development of the Russian industry. It is the promising and breakthrough nature of innovations investment that makes it impossible for the state to participate as a dominant investor. Its role is being optimized as a service organization contributing to the acceleration of the development of high-tech business in promising areas both within the country and in world markets. In addition, the National Technology Initiative supports broad international engagement.

With regard to the mining complex, the promising markets for the introduction of Industry 4.0 within the framework of the National Technology Initiative are SafeNet (creation of modern safety and labor protection tools, monitoring technogenic risks), EnergyNet (new digital technologies in energy production and energy production), AeroNet (use of unmanned aerial vehicles and devices for creating "digital clones" of deposits and mining enterprises), NeuroNet (the use of artificial intelligence for the development and adoption of engineering solutions and management of unmanned industrial complexes), EduNet (digital mining education), EcoNet (digital models for optimizing resource consumption).

\section{Results and Discussion}

The platform of the National Technology Initiative - Industry 4.0 - forms Smart Mining in extractive sector. It represents a wide range of technological, technical, managerial and 
financial solutions that provide the following breakthrough directions for the development of a modern mining industry [10]:

- more accurate determination of the volume of minerals to be extracted at current prices and costs;

- optimization of material flows and equipment capacity;

- improved forecasting of failures, increased automation such as mine surveying using drones and 3D laser technology;

- virtual digital training of personnel;

- automated mobile equipment pools with artificial intelligence in dispatching, robotic segments.

In a Smart Mining system, it is also possible to provide real-time monitoring of equipment performance and safety of personnel. Through the use of the Internet of Things (IoT) [11], Big Data, machine-to-machine communication (M2M), artificial intelligence for data analytics, Smart Censors [12] on excavators, drilling rigs, dump trucks, observation drones, intelligent mining, also called Mining 4.0, based on digital and robotic technologies of Industry 4.0, will completely exclude a human from drilling and blasting, excavation and loading, transport processes, geodetic surveying, planning and operational management [1315]. At the same time, the highest degree of coordination and flexibility in managing the processes of mining operations will ensure profitable mining at any level of prices and demand for raw materials in the global and domestic markets. The evolution of Mining 4.0 is presented in Tab. 1.

Table 1. Relationship between the stages of industrial development, geotechnology and the evolution of Mining 4.0

\begin{tabular}{|c|c|c|c|c|}
\hline Period & $\begin{array}{c}\text { Industry } \\
\text { development } \\
\text { stages }\end{array}$ & $\begin{array}{c}\text { Technological } \\
\text { innovations }\end{array}$ & $\begin{array}{c}\text { Stages of } \\
\text { development } \\
\text { of } \\
\text { geotechnology }\end{array}$ & $\begin{array}{c}\text { Mining } \\
\text { innovation }\end{array}$ \\
\hline $\begin{array}{c}18-19 \\
\text { centuries }\end{array}$ & Industry 1.0 & $\begin{array}{c}\text { Coal coke, steam } \\
\text { engines, natural gas } \\
\text { production }\end{array}$ & Mining 1.0 & $\begin{array}{c}\text { Mechanization } \\
\text { of auxiliary } \\
\text { processes }\end{array}$ \\
\hline $\begin{array}{c}\text { Second } \\
\text { half of } \\
\text { the 19th - } \\
\text { early } \\
20 \text { th } \\
\text { centuries }\end{array}$ & Industry 2.0 & $\begin{array}{c}\text { Electricity, line } \\
\text { production, oil and } \\
\text { non-ferrous metals, } \\
\text { internal combustion } \\
\text { engines }\end{array}$ & Mining 2.0 & $\begin{array}{c}\text { Mechanization } \\
\text { of the main } \\
\text { processes }\end{array}$ \\
\hline $\begin{array}{c}\text { Second } \\
\text { half of } \\
\text { the } 20 \\
\text { century. }\end{array}$ & Industry 3.0 & $\begin{array}{c}\text { Automation, analog } \\
\text { computing and } \\
\text { control systems }\end{array}$ & Mining 3.0 & $\begin{array}{c}\text { High specific } \\
\text { performance } \\
\text { equipment, } \\
\text { analog }\end{array}$ \\
\hline $\begin{array}{c}\text { The } \\
\text { beginning } \\
\text { of the } 21 \\
\text { century. }\end{array}$ & Industry 4.0 & $\begin{array}{c}\text { Intemetry } \\
\text { Internet of Things, } \\
\text { artificial } \\
\text { intelligence, } \\
\text { convergent } \\
\text { technologies }\end{array}$ & Mining 4.0 & $\begin{array}{c}\text { Unmanned } \\
\text { technologies, } \\
\text { remote process } \\
\text { control, digital } \\
\text { modeling }\end{array}$ \\
\hline
\end{tabular}


From Tab. 1 it follows that the development of mining actually reflects the demand of the industry for new types and growing volumes of industrial raw materials. Prospects for the Industry 4.0 digital technologies diffusion in the mining industry - one of the most conservative sectors of the economy - are associated with global competition in the raw materials market [16-18]. In the coming decades, the volume of production at each mine and open pit will depend on world prices and demand. That is, future mining will become a derived value from global prices determined by international competition [19]. The mining industry has overcome many challenges with new technologies, but information technology alone will not be enough in the future [20]. Despite the fact that the technological aspect of mining is at the forefront of the innovative development of the industry, one of the most important conditions for the survival of mining enterprises will be the availability of a competent workforce capable of coping with the latest information technology [21]. And this, in turn, poses the problem of the synchronous change of generations not only of technology, but also of workers [22].

The directions of Mining 4.0 development and the place of ultramodern technologies in it are shown in detail in Fig. 2.

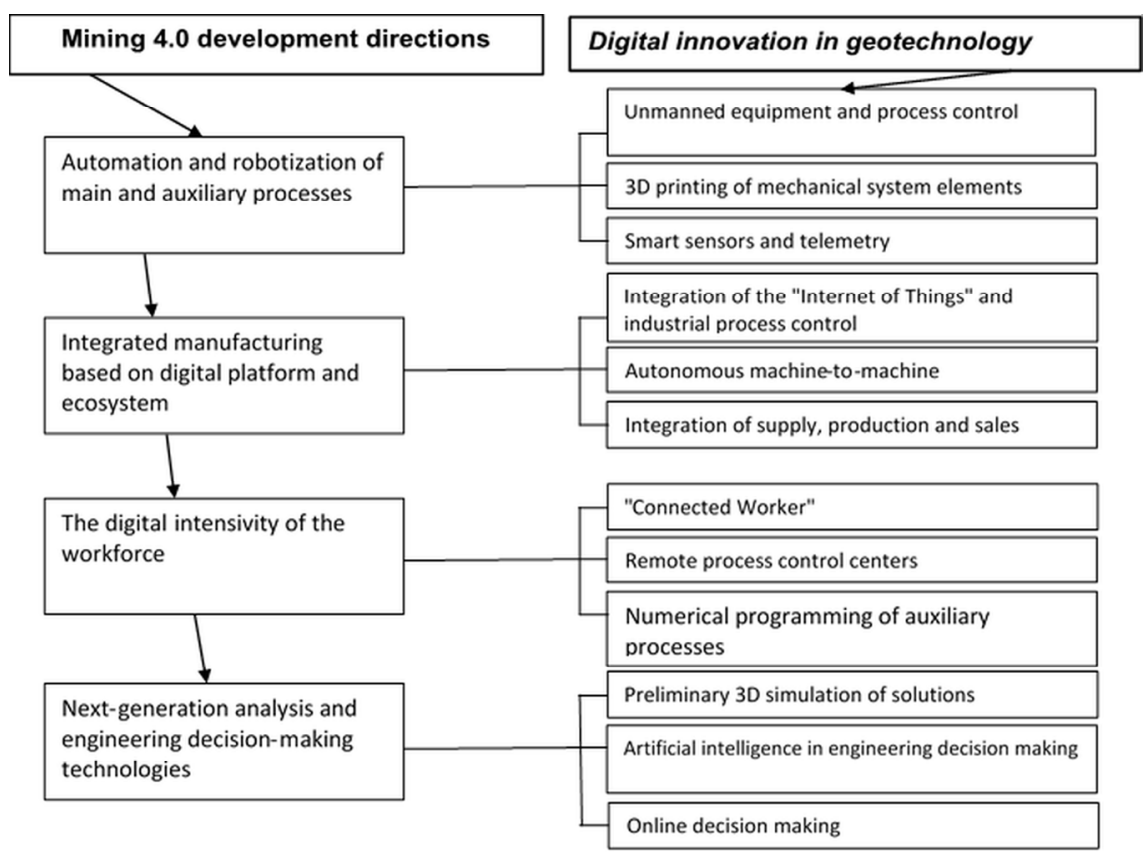

Fig. 1. Ways of development of Mining 4.0 and digitalization of technological, managerial, financial and economic processes in mining.

The evolution of digital technology for visualizing engineering, organizational and managerial processes, creating digital clones of mining enterprises, unmanned automation of equipment operation, by the end of 2030 are expected to create jobs for miners, who will in fact be dispatchers and strategic planners of a complex set of intertwining processes controlled by artificial intelligence [23-25]. Already today, "smart" sensors, drones, 3D cameras and modern methods of processing big data allow making engineering and management decisions ahead of the emergence of problems in the activities of mining enterprises, which significantly reduces production costs [26-30]. 


\section{Conclusion}

Industry 4.0, which is widely reflected in the National Technology Initiative, is implemented in the mining industry of countries - world leaders of mineral resource extraction. It generates new elements of mining technologies (Mining 4.0). Such a technological base of the future mineral resource sector is distinguished by a wide level of implementation of unmanned production, digital modeling as a means of ultra-fast and reliable operational control of mining processes and the highest labor safety. The existing experience in the implementation of Mining 4.0 technologies has shown a significant increase in productivity, labor and environmental safety, profitability of mining. This is achieved during searching for new forms of connecting humans and artificial intelligence, for example, in the framework of direct emulation of design of remote control of equipment and mining operations. We associate the prospects for the development of Mining 4.0 technologies in the Russian economy with the promotion of the National Technology Initiative.

\section{Acknowledgement}

This study was financed by a grant from the Plekhanov Russian University of Economics.

\section{References}

1. National Technology Initiative. Russian Federation. URL: https://nti2035.ru/nti/

2. M.E. Konovalova, O.Y. Kuzmina, S.A. Zhironkin, Lecture Notes in Networks and Systems 84, 180-188 (2020)

3. L.S. Sagdeeva, L.N. Starikova, Economics and Innovation Management 1, 55-67 (2019) DOI: 10.26730/2587-5574-2019-1-55-67

4. M.A. Klimovich, Economics and Innovation Management 1, 18-25 (2019) DOI: 10.26730/2587-5574-2019-1-18-25

5. N. Ezdina, E3S Web Conf. 21, 04015 (2017)

6. E. Dotsenko, E3S Web Conf. 21, 04013 (2017)

7. E. Dotsenko, N. Ezdina, S. Mudrova, E3S Web Conf. 105, 02008 (2019)

8. S.K. Demchenko, M.S. Zlotnikov, T.A. Melnikova, O.S. Demchenko, International Journal of Civil Engineering and Technology 10(2), 1877-1884 (2019)

9. S. Zhironkin, O. Aleshina, V. Gorev, Y. Gunyakov, O. Zhironkina, E3S Web Conf. 105, 04001 (2019)

10. M. Tyulenev, S. Markov, M. Cehlar, S. Zhironkin, M. Gasanov, Acta Montanistica Slovaca 23(4), 368-377 (2018)

11. O. Kalenov, S. Kukushkin, E3S Web Conf. 174, 02024 (2020)

12. S. Kukushkin, O. Kalenov, R. Kamanina, O. Kosareva, E3S Web Conf. 174, 04014 (2020)

13. M. Tutak, J. Brodny, D. Szurgacz, L. Sobik, S. Zhironkin, Energies 13(18), 4891 (2020)

14. F.N. Abu-Abed, L.G. Naumova, Journal of Mining and Geotechnical Engineering 3, 21 35 (2019) doi: 10.26730/2618-7434-2019-3-21-35

15. D. Dubinkin, V. Aksenov, M. Tyulenev, S. Markov, Journal of Mining and Geotechnical Engineering 4, 42-69 (2020) doi: 10.26730/2618-7434-2020-4-42-69

16. A. P. Dzyuba, Economics and Innovation Management 1, 51-62 (2021) DOI: $10.26730 / 2587-5574-2021-1-51-62$ 
17. G.S. Armashova-Telnik, Economics and Innovation Management 4, 36-42 (2018) DOI: 10.26730/2587-5574-2018-4-36-42

18. M. Cehlár, P. Rybár, J. Mihók, J. Engel, Journal of Mining and Geotechnical Engineering 1, 4-23 (2019) doi: 10.26730/2618-7434-2019-1-04-23

19. J. Lööw, L. Abrahamsson, J. Johansson, Mining, Metallurgy \& Exploration 36, 701-707 (2019)

20. V.F. Kolesnikov, J. Janočko, Journal of Mining and Geotechnical Engineering 2, 42-74 (2020) doi: 10.26730/2618-7434-2020-2-42-74

21. Z. Šimková, M. Cehlár, H. Pavolová, M.A. Tyulenev, Economics and Innovation Management 3, 47-58 (2020) DOI: 10.26730/2587-5574-2020-3-47-58

22. M. Yazevich, O. Kalinina, O.Zhironkina, E3S Web Conf. 134, 03004 (2019)

23. F. Abu-Abed, E3S Web Conf. 105, 03006 (2019)

24. M. Cehlar, Economics and Innovation Management 3, 24-31 (2019) DOI: 10.26730/2587-5574-2019-3-24-31

25. Cehlar, M. Vodzinsky, V. Acta Montanistica Slovaca 6, 42-55 (2001)

26. V. Frolova, O. Dolina, T. Shpilkina, E3S Web Conf. 174, 04025 (2020)

27. N. Kazitskaya, V. Prusova, S. Bochkov, E3S Web Conf. 174, 04045 (2020)

28. I. Politkovskaya, D. Khvichiya, L. Artamonova, E3S Web Conf. 174, 04047 (2020)

29. N. Amirova, L. Sargina, A. Khasanova, E3S Web Conf. 174, 02011 (2020)

30. N. Rebrowa, A. Kovalev, O.V. Frik, G. Sargsyan, E3S Web of Conf. 174, 04054 (2020) 